\title{
Effects of prayer on the vital signs of patients with chronic kidney disease: randomized controlled trial*
}

\author{
Efeitos da prece nos parâmetros vitais de pacientes com \\ insuficiência renal crônica: ensaio clínico randomizado \\ Efectos de la plegaria en los parámetros vitales de pacientes con \\ insuficiencia renal crónica: ensayo clínico randomizado
}

Thaila Oliveira Zatiti Brasileiro', Andressa Anunciação de Oliveira Prado ${ }^{1}$ Bianca Bacelar de Assis ${ }^{1}$, Denismar Alves Nogueira ${ }^{1}$, Rogério Silva Lima ${ }^{1}$, Erika de Cassia Lopes Chaves ${ }^{1}$

How to cite this article:

Brasileiro TOZ, Prado AAO, Assis BB, Nogueira DA, Lima RS, Chaves ECL. Effects of prayer on the vital signs of patients with chronic kidney disease: randomized controlled trial. Rev Esc Enferm USP. 2017;51:e03236. DOI: http://dx.doi.org/10.1590/S1980-220X2016024603236

* Extracted from the undergraduate scientific work "Contribuiçôes da prece sobre a hipertensão arterial, frequência cardíaca, respiratória e ansiedade de pessoas com IRC em tratamento de hemodiálise", Universidade Federal de Alfenas, 2016.

${ }^{1}$ Universidade Federal de Alfenas, Escola de Enfermagem, Alfenas, MG, Brazil.

\begin{abstract}
Objective: To assess the effect of prayer on blood pressure, heart rate and respiratory rate in patients with chronic kidney disease and learn their perception of the intervention.

Method: A randomized controlled trial, double blind with a sample of volunteers, randomized into an intervention group $(n=42)$ and a control group $(n=37)$. Questionnaires addressing socio-demographic, clinical and spiritual characteristics and the Duke University Religious Index were applied. Blood pressure, heart rate and respiratory rate were measured. The prayer was conducted at three different moments on alternating weeks. The qualitative data were organized and analyzed through Thematic Analysis. Results: The sample consisted of 95 randomized volunteers. In the intra-group analysis, a statistically significant reduction $(\mathrm{P}<0001)$ of blood pressure, heart rate and respiratory rate was observed in all evaluations of the people who were prayed for. The qualitative analysis resulted in the themes Prayer in a "Place of Suffering" and Positive Evaluation and in the sub-themes Relief from Suffering, Hope for Improvement, and Coping with Hemodialysis. Conclusion: Prayer reduced blood pressure, heart rate and respiratory rate in patients who suffer from chronic kidney disease, and the volunteers' evaluation of the intervention was positive. Brazilian Clinical Trials Registry: RBR-2zv39y.
\end{abstract}

DESCRIPTORS

Arterial Pressure; Renal Insufficiency; Spirituality; Faith Healing; Holistic Nursing.

Corresponding author:

Erika de Cassia Lopes Chaves

Rua Gabriel Monteiro, 700 - Centro

CEP 37130-000 - Alfenas, Minas Gerais, Brazil

echaves@usp.br 


\section{INTRODUCTION}

Chronic kidney disease (CKD) is considered a global public health problem nowadays and it has attracted attention from health researchers' due to the increase in prevalence reported in the literature. Estimated prevalence ranges from $8 \%$ to $16 \%$ worldwide, and prevalence is high in developed and developing countries ${ }^{(1)}$. The disease is described as damage to the renal tissue and/or gradual loss of the glomerular filtration rate (GFR), with a rate of less than 60 $\mathrm{mL} / \mathrm{min} / 1.73 \mathrm{~m}^{2}$ for 3 months or more ${ }^{(2)}$.

One of the elements that can lead to the development of CKD is Hypertension. These two conditions are closely related, since renal disease can cause hypertension, and this, in turn, can cause renal disease ${ }^{(3)}$. When renal function is impaired laboratory manifestations arise, such as hydroelectrolytic, metabolic and hormonal imbalances and clinical manifestations such as anemia, anorexia and weight and height growth delays ${ }^{(2)}$.

The main course of treatment for advanced CKD is hemodialysis, which has the function of replacing or supporting renal function through an extracorporeal device reproducing glomerular filtration and removing toxic substances and excessive fluids ${ }^{(4)}$. Hemodialysis aims at reversing uremic symptoms and reducing complications inherent in the procedure, such as hypertension, which is characterized by vascular resistance in relation to cardiac output and is common in patients undergoing hemodialysis for 4-hour periods ${ }^{(5)}$.

The hemodialysis treatment increases the patient's life expectancy, but most of the times it also causes physical, emotional, social and spiritual losses, since it can lead to impairment of mobility, recreation, autonomy and other factors. Therefore, it is important the person with CKD finds coping strategies for dealing not only with the disease and its treatment, but also with its consequences. In this context, spirituality is an internal resource assisting in accepting the disease, promoting social interaction and even affecting the rehabilitation process, especially in critical situations such as $\mathrm{CKD}^{(6-7)}$.

In addition, spirituality can lead to an optimistic perspective, often capable of building a positive attitude that can serve as therapeutic support and as an important element in the care of the person ${ }^{(8)}$.

Prayer is an important spiritual experience, as precari is a word originating from Latin, which means "to ask earnestly, beg, entreat ${ }^{\prime \prime}(9)$. It is a spiritual activity often used by patients and it can facilitate the health/disease transition process and promote well-being. Prayer is more than just a resource for promoting religious/spiritual coping, it also promotes hope by providing a connection to a sacred and transcending dimension $^{(10)}$. It also helps people to feel stronger and safer in facing the disease, the treatment and the whole context they are included in ${ }^{(11)}$. A study ${ }^{(11)}$ found that prayer is an effective spiritual strategy to reduce anxiety during the treatment of critically ill patients.

Thus, professionals involved in health care should be encouraged to take actions in the spiritual realm, such as prayer, during the process of coping with illness ${ }^{(12)}$, bearing in mind that the care provided to the patients should follow a holistic approach, meaning that all the patients' needs should be addressed, as it is often established in professional codes of ethics and health policies ${ }^{(13)}$. Prayer is regarded as an intervention and a way of attending to the person's spiritual needs, in the context of nursing ${ }^{(14)}$. Therefore, this intervention should be part of the activities carried out by health professionals, especially nurses, during the performance of their habitual practices, in order to provide advantages to conventional treatment and attend to the patients' spirituality ${ }^{(13)}$.

According to the results of the study ${ }^{(13)}$, using prayer in clinical practice can provide multiple beneficial effects, such as reduction of mortality in patients with bloodstream infections, reduction of anxiety, and depression and better physical functioning.

This study aimed at assessing the effect of prayer on blood pressure, heart rate, and respiratory rate of patients with CKD during hemodialysis; based on the outlined scenario and considering the unique character of prayer and its relevance on health care. The study also assessed the patients' perceptions of being prayed for as a complementary intervention during the hemodialysis session.

\section{METHOD}

The present study consisted of two phases. The first was a controlled, randomized, and double blind clinical trial. The second phase was a qualitative, exploratory, descriptive, and cross-sectional study. The study was conducted in a hemodialysis unit attached to a philanthropic hospital located in the southern part of Minas Gerais state. Approval of the Research Ethics Committee of UNIFAL-MG was obtained, registered as number 845.002 (CAAE \# 31109714.3.0000.5142) and the study was registered in the Brazilian Clinical Trials Registry - Rebec (RBR-2zv39y). The volunteers agreed to participate through the signing of a consent form. The participants were identified by the letter $\mathrm{E}$ followed by an Arabic number in order to preserve anonymity.

\section{STUDY PARTICIPANTS}

The volunteers were patients with CKD on hemodialysis (HD) treatment, consisting of a population of 160 people. The inclusion criteria were: having arterial hypertension higher than the reference value $(\geq 140 / 90 \mathrm{mmHg})^{(15)}$, being 18 years old or older, being oriented in time, space and person, being able to express oneself orally, and the wish to be prayed for. The exclusion criteria were: patients who were deaf and/or had compromised speech limitations.

A total of 42 patients did not meet the inclusion criteria from the population and 23 refused to participate in the study, therefore the sample consisted of 95 volunteers, randomized into the intervention group (IG) $(n=50)$ and control group $(\mathrm{CG})(\mathrm{n}=45)$. Eight volunteers in each group were not followed-up. Thus, the IG consisted of 42 volunteers who were prayed for as intervention, and the CG consisted of 37 volunteers (Figure 1). 


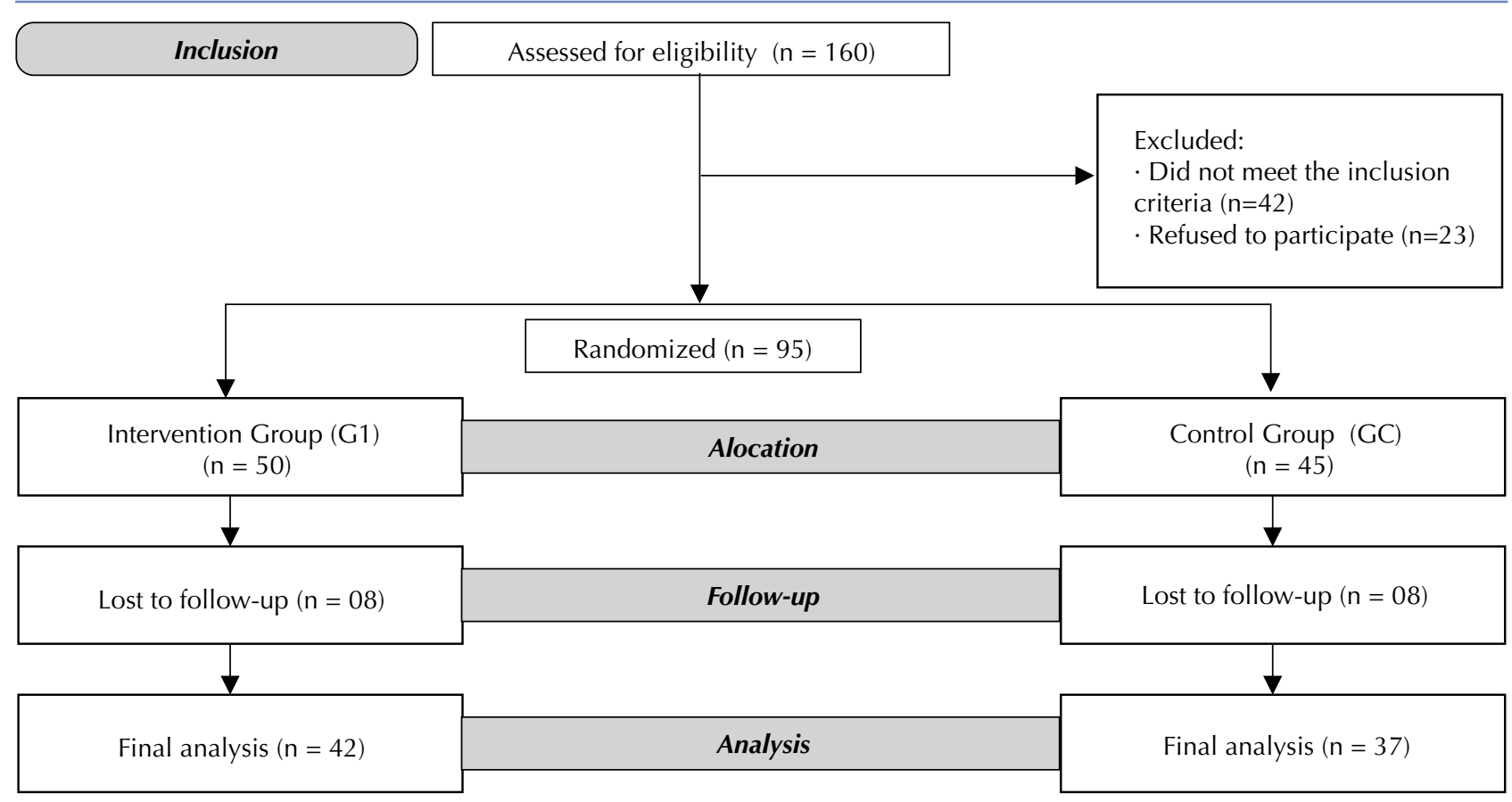

Figure 1 - Flowchart adapted from Consort ${ }^{(16)}$ - Alfenas, Minas Gerais, Brazil, 2016.

\section{DATA COLLECTION INSTRUMENTS}

A questionnaire was applied through an interview in order to assess socio-demographic, religious and clinical characteristics (time of treatment and presence of comorbidity). The Duke Religious Index (DUREL) was used to assess religiosity.

DUREL is a Brazilian validated scale ${ }^{(17)}$ that assesses three dimensions of religiosity ${ }^{(18)}$ : organizational religious activity (ORA), non-organizational religious activity (NORA) and intrinsic religiosity (IR). Scores on the three dimensions should be examined independently ${ }^{(18)}$. For ORA and NORA, a score lower than three characterizes high levels of religious activity; scores greater than three indicate low levels of religious activity. For the IR item, a score below 7.5 characterizes a high level of religiosity, and scores higher than 7.5 indicate a low level of religiosity.

\section{Application OF THE INTERVENTION}

The participants of the IG participated in the intervention, which consisted in listening to a prayer according to suggested protocol ${ }^{(11)}$ : reading a Christian supplication prayer, without invocating saints, based on Psalm 138, which speaks of divine omniscience. The prayer lasted 11 minutes and was recorded by a musician whose voice displayed good diction and was listened to wearing earphones with a plastic protection. The patients were asked to stay in a comfortable position and close their eyes in order to abide in a moment of concentration. The prayer was heard three times by each patient in alternating weeks, during the HD sessions and in the presence of the same professional in each intervention, who stood beside the patient.

The CG participants did not listen to the prayer; the professional only made an informal visit of the same duration as the intervention and had a conversation about what the patient wished to talk about.

\section{EVALUATION PROCEDURE}

For clinical evaluation, blood pressure (BP), heart rate (HR), and respiratory rate (RR) were measured. The BP and $H R$ were measured according to the recommendations of the Ministry of Health ${ }^{(15)}$ and through the validated Omron digital sphygmomanometer (HEM 7200)(19), as recommended by the British Hypertension Society (BHS) ${ }^{(20)}$. A minimum of 20 minutes of rest was taken after the start of the HD session, during which the patient remained seated, resting the back against an armchair in a reclining position with feet resting on an anatomical rest. The rates were measured on the free member of the arteriovenous fistula $(\mathrm{AVF})$, which was placed on the armrest and remained at the height of the cardiac region, with the palm of the hand pointed upwards and the elbow slightly flexed.

$\mathrm{RR}$ was measured by palpating the chest and counting the thoracic respiratory movements for one minute, using an analog clock and not letting the patient perceive the examiner's intention ${ }^{(21)}$.

Two evaluation sessions were conducted for each administered intervention. The first was called the pre-intervention evaluation, which occurred at the beginning of the HD session, before the application of the prayer. Third minutes after the invention started, the same vital data were assessed, which constituted the second evaluation session, or post-evaluation.

It should be noted that both the IG and CG patients were assessed in all the evaluations, maintaining the same standards in the technique and in the measurement sequence and also performed by the same examiner. Moreover, the double blind was maintained in the study, since neither the statistician nor the examiner knew if the patient was allocated in the IG or in the CG, information known only by the professional who prayed. 
Data was collected from November 2014 to February 2015. At the end of data collection, the volunteers in the IG, who were prayed for, were invited for an interview, which was audio-recorded in a digital recorder and guided by the following questions: What do you think about the prayer during the hemodialysis session? Why? Do you have anything to say about the prayer during your treatment? A total of 35 people agreed to record the interview and seven refused to participate among the 42 patients in the intervention group in this stage of the study claiming they were tired from the hemodialysis session.

\section{AnALysis of Results}

The results obtained from the instruments and the evaluation of vital data were tabulated on an electronic spreadsheet, with double type data entry and validation. For comparing the IG and CG, the data were analyzed using SPSS software, version 22.0. The Chi-square and MannWhitney tests were used for two independent samples, the Fisher's Exact test was used to confirm the homogeneity of the sample, and the Wilcoxon signed-rank test was used to compare the pre- and post-intervention results of blood pressure, heart rate, and respiratory rates. Significance was set at $5 \%$. A statistical power over $80 \%$ was adopted as the reference $^{(22)}$. The diastolic blood pressure (DBP) variable displayed a statistical power of $97 \%$, which indicates the suitability of the sample for the design of the present study.

The audio recordings were completely transcribed, organized, and analyzed through Thematic Analysis (TA) ${ }^{(23)}$.

TA is a method used to identify, analyze, and report patterns in the data, which involves an active role of the researcher in identifying and selecting patterns relevant to the research question. These patterns of answers in the data, when related to the objective of the research, are called themes. Six phases are proposed to perform the TA: familiarization with data; generating initial codes; searching for themes; reviewing themes; defining and naming themes; and producing the final report. The present study followed all previously described phases, as proposed by Braum and Clarke (2006).

\section{RESULTS}

Table 1 shows the distribution of the individuals included in the sample according to socio-demographic characteristics. It is possible to verify the homogeneity of the IG and CG regarding the gender, age, marital status, and occupation variables. The \pm standard deviation in the mean age of the IG participants ranged from 20 to 78 years old $(53.24 \pm 14.42)$, and for the CG it ranged from 23 to 90 years old $(60.70 \pm 15.18)$.

Table 1 - Characterization of the sample regarding socio-demographic profile, distributed in IG (Intervention Group) and CG (Control Group) - Alfenas, Minas Gerais, Brazil, 2016.

\begin{tabular}{|c|c|c|c|c|}
\hline SOCIO-DEMOGRAPHIC VARIABLES & & $\begin{array}{c}\text { IG }(n=42) \\
f(\%)\end{array}$ & $\begin{array}{c}\text { CG }(n=37) \\
f(\%)\end{array}$ & P Value \\
\hline \multirow{3}{*}{ Gender } & Female & $14(33.3)$ & $15(40.5)$ & \multirow{3}{*}{$0.507^{1}$} \\
\hline & & & & \\
\hline & Male & $28(66.7)$ & $22(59.5)$ & \\
\hline \multirow{5}{*}{ Age } & 20 to 40 years old & $7(16.7)$ & $4(10.8)$ & \multirow{5}{*}{$0.081^{2}$} \\
\hline & 41 to 50 years old & $7(16.7)$ & $3(8.1)$ & \\
\hline & 51 to 60 years old & $11(26.2)$ & $12(32.4)$ & \\
\hline & 61 to 70 years old & $15(35.7)$ & $8(21.6)$ & \\
\hline & $>71$ years old & $2(4.8)$ & $10(27.0)$ & \\
\hline \multirow{7}{*}{ Educational level } & No formal education & $2(4.8)$ & $6(16.2)$ & \multirow{7}{*}{$0.038^{2}$} \\
\hline & Incomplete primary education & $21(50)$ & $19(51.4)$ & \\
\hline & Complete primary education & $2(4.8)$ & $7(18.9)$ & \\
\hline & Incomplete secondary education & $6(14.3)$ & $1(2.7)$ & \\
\hline & Complete secondary education & $7(16.7)$ & $3(8.1)$ & \\
\hline & Incomplete higher education & - & $1(2.7)$ & \\
\hline & Complete higher education & $4(9.5)$ & - & \\
\hline \multirow{5}{*}{ Marital status } & Single & $9(21.4)$ & $11(29.7)$ & \multirow{5}{*}{$0.566^{1}$} \\
\hline & Married & $26(61.9)$ & 17 (45.9) & \\
\hline & & & & \\
\hline & Divorced & $3(7.1)$ & $4(10.8)$ & \\
\hline & Widowed & $4(9.5)$ & $5(13.5)$ & \\
\hline
\end{tabular}




\begin{tabular}{|c|c|c|c|c|}
\hline \multicolumn{5}{|l|}{...continuation } \\
\hline SOCIO-DEMOGRAPHIC VARIABLES & & $\begin{array}{c}\text { IG }(n=42) \\
f(\%)\end{array}$ & $\begin{array}{c}C G(n=37) \\
f(\%)\end{array}$ & P Value \\
\hline \multirow{4}{*}{ Occupation } & Yes & $5(11.9)$ & $2(5.4)$ & \multirow{4}{*}{$0.759^{1}$} \\
\hline & Retired & $23(54.8)$ & $23(62.2)$ & \\
\hline & Illness benefit* & $11(26.2)$ & $9(24.3)$ & \\
\hline & Dependent on family & $3(7.1)$ & $3(8.1)$ & \\
\hline \multirow{5}{*}{ Monthly family income } & One minimum wage** & $6(14.3)$ & $11(29.7)$ & \multirow{5}{*}{$0.024^{2}$} \\
\hline & Two to three minimum wages & $28(66.7)$ & $24(64.9)$ & \\
\hline & Four to five minimum wages & $3(7.1)$ & $2(5.4)$ & \\
\hline & Six to ten minimum wages & $3(7.1)$ & - & \\
\hline & More than 10 wages & $2(4.8)$ & - & \\
\hline
\end{tabular}

${ }^{1}$ Chi-Square Test; ${ }^{2}$ Mann-Whitney Test.

*Benefit given by the government to people who do not work due to health issues, and therefore receive an illness benefit.

**The current minimum wage in Brazil in 2015 was $\mathrm{R} \$ 788.00$.

The \pm standard deviation in mean time of treatment varied from 3 months to 16 years $(4.33 \pm 4.53)$ for the IG and from 1 to 23 years $(6.16 \pm 5.68)$ for the CG. Table 2 displays the clinical characteristics of the subjects, showing homogeneity regarding the presence of comorbidities associated with $\mathrm{CKD}$, with emphasis on the presence of diabetes and hypertension in both groups. Regarding time of treatment, the IG displayed a higher number of subjects who had undergone less than 5 years of treatment.
Table 2 also shows the religious and spiritual characteristics of the participants, which are also homogeneous between the groups. Although one patient declared himself as an atheist and two of them had no specific religion, they accepted to participate in the study after clarification about the type of intervention they would get and were included in the final analysis of the results, since the "religion" variable did not display a statistically significant difference ( $\mathrm{p}=0.0946$ ) between the groups (Table 2 ).

Table 2 - Profile of the sample according to religious and spiritual characteristics, distributed in IG (Intervention Group) and CG (Control Group) - Alfenas, Minas Gerais, Brazil, 2016.

\begin{tabular}{|c|c|c|c|c|}
\hline \multicolumn{2}{|c|}{ RELIGIOUS/SPIRITUAL CHARACTERISTICS } & $\begin{array}{c}\text { IG }(n=42) \\
f(\%)\end{array}$ & $\begin{array}{c}\text { CG }(n=37) \\
f(\%)\end{array}$ & P Value \\
\hline \multirow{3}{*}{ Time of treatment } & 0 to 5 years & $30(71.4)$ & $16(43.2)$ & \multirow{3}{*}{$0.030^{3}$} \\
\hline & 6 to 10 years & $4(9.5)$ & $11(29.7)$ & \\
\hline & Over 10 years & $8(19.0)$ & $10(27.0)$ & \\
\hline \multirow{2}{*}{ Comorbidity associated with CKD } & Has & $24(57.1)$ & $19(51.5)$ & \multirow{2}{*}{$0.606^{2}$} \\
\hline & Does not have & $18(42.9)$ & $18(48.6)$ & \\
\hline \multirow{4}{*}{ Religion } & Atheist & - & $1(2.7)$ & \multirow{4}{*}{$0.0946^{1}$} \\
\hline & No specific religion & - & $2(5.4)$ & \\
\hline & Catholic & $36(85.7)$ & $25(67.6)$ & \\
\hline & Evangelical & $6(14.3)$ & $9(24.3)$ & \\
\hline \multirow{2}{*}{ Practices a religion } & Yes & $27(64.3)$ & $23(62.2)$ & \multirow{2}{*}{$0.845^{2}$} \\
\hline & No & $15(35.7)$ & $14(37.8)$ & \\
\hline \multirow{4}{*}{ Importance of religion/spirituality } & Not important & - & $2(5.4)$ & \multirow{4}{*}{$0.4931^{1}$} \\
\hline & Not very important & $1(2.4)$ & $1(2.7)$ & \\
\hline & Important & 8 (19.0) & $9(24.3)$ & \\
\hline & Very important & $33(78.6)$ & $25(67.6)$ & \\
\hline \multirow{2}{*}{ Believes in the power of prayer } & Yes & 41 (97.6) & $33(89.2)$ & \multirow{2}{*}{$0.125^{2}$} \\
\hline & No & $1(2.4)$ & $4(10.8)$ & \\
\hline
\end{tabular}

${ }^{1}$ Fisher's Exact Test; ${ }^{2}$ Chi-Square Test; ${ }^{3}$ Mann-Whitney Test.

Two (4.8\%) participants stated they do not say any kind of prayer in the IG and 40 (94.2\%) reported they do. Out of these, $30(71.4 \%)$ pray daily, eight (19.0\%) pray more than once a day and two (4.8\%) pray sometimes. In the CG, two (5.4\%) do not say any kind of prayer and 35 (94.6\%) do. Among these, 25 (71.4\%) pray daily, seven (20.0\%) pray 
more than once a day and three $(8.6 \%)$ pray sometimes. Only one participant (2.4\%) of the IG reported participating in spiritual support groups. In the CG, four (10.8\%) participants reported participating in support groups and having some kind of spiritual treatment.

The sample was homogeneous $(P>0.005)$ and displayed a high level of religiosity on the three dimensions (Organizational Religious Activity, Non-Organizational Religious Activity and Intrinsic Religiosity) regarding the analysis of the religiosity of the participants based on the DUREL scale. In the IG, ORA score was 2.78, NORA score was 2.1 and IR score was 3.74. The ORA score was 3.19, NORA score was 2.3, and IR score was 4.78 in the CG. Therefore, both groups displayed high levels of religiosity, mostly regarding intrinsic religiosity, which is related to a search for internalizing and fully living the religious experience: feeling the presence of God and striving to live religious beliefs. The CG expressed low levels of religiosity regarding ORA (score $>3$ ).

It was possible to determine from the results obtained in the intra- and inter-group analysis (IG and CG) that vital signs evaluated in IG exhibited reduced values after three interventions, which was statistically significant $(\mathrm{P}<0.001)$, indicating the efficacy of prayer in reducing hypertension (Table 3). In the CG an increase was uncovered in vital signs measured post-intervention, with statistical significance for SBP and RR $(\mathrm{P}<0.001)$ and similarity in the DBP and HR. However, when comparing vital signs between the groups, statistical significance was found in the HR and RR variables (Table 3).

Table 3 - Intra- and inter-group (IG and CG) comparisons of the mean values of diastolic blood pressure (DBP), systolic blood pressure (SBP) heart rate (HR) and respiratory rate (RR) - Alfenas, Minas Gerais, Brazil, 2016.

\begin{tabular}{|c|c|c|c|c|c|c|c|}
\hline \multirow[b]{2}{*}{ VARIABLES } & \multicolumn{2}{|c|}{ IG $(n=42)$} & \multirow[b]{2}{*}{$p$ value $^{1}$} & \multicolumn{2}{|c|}{ CG $(n=37)$} & \multirow[b]{2}{*}{$p$ value $^{1}$} & \multirow{2}{*}{$\begin{array}{c}\text { Post-intervention } \\
\text { p value }{ }^{2} \\
\text { inter-groups }\end{array}$} \\
\hline & Pre & Post & & Pre & Post & & \\
\hline SBP & 145.9 & 136.9 & $<0.001$ & 138.1 & 143.4 & $<0.001$ & 0.137 \\
\hline DBP & 86.1 & 82.8 & $<0.001$ & 79.5 & 80.2 & 0.224 & 0.103 \\
\hline$H R$ & 75.6 & 71.4 & $<0.001$ & 73.4 & 73.8 & 0.402 & 0.027 \\
\hline RR & 18.5 & 17.2 & $<0.001$ & 18.9 & 19.5 & $<0.001$ & $<0.001$ \\
\hline
\end{tabular}

${ }^{1}$ Wilcoxon signed-rank test; ${ }^{2}$ Mann-Whitney Test.

The organization and analysis of the testimonies of the IG members on prayer as a complementary intervention resulted in two main themes: Prayer in a "place of suffering" and Positive Evaluation, and three sub-themes:
Relief from Suffering, Hope for Improvement, and Coping with Hemodialysis.

The themes, sub-themes, and the statements that represent them are shown in Chart 1.

Chart 1 - Themes, sub-themes, and statements of the volunteers in the Intervention Group (IG) on prayer as a complementary intervention - Alfenas, Minas Gerais, Brazil, 2016.

\begin{tabular}{|c|c|}
\hline $\begin{array}{l}\text { Theme 1: PRAYER IN A } \\
\text { "PLACE OF SUFFERING" }\end{array}$ & $\begin{array}{l}\text { (...) we get sort of (cries) sad due to this problem and only God can help us (...) (E17). } \\
\text { (...) because we know here what we are going through, we know the troubles and the difficulties (...) (E24). }\end{array}$ \\
\hline $\begin{array}{l}\text { Sub-theme: Relief from } \\
\text { Suffering }\end{array}$ & $\begin{array}{c}\text { (...) I think it's good, very good (...) we get here with a sad heart and the prayer already helps a little (...) (E6). } \\
\text { (...) it is very interesting, it was really beyond faith, I was kind of depressed, sad (...) for me it was beautiful to pray, to } \\
\text { listen to prayer on these days (...) (E4). }\end{array}$ \\
\hline $\begin{array}{l}\text { Theme 2: POSITIVE } \\
\text { EVALUATION }\end{array}$ & $\begin{array}{r}\text { (...) the words shared with us are loving (...) this prayer was very important, it is like our daily food, it satisfies us, satis- } \\
\text { fies all our daily needs (E28). } \\
\qquad \begin{array}{r}\text { I think it is fundamental to my treatment (...) prayer, religion, it is so important to us (E33). }\end{array}\end{array}$ \\
\hline $\begin{array}{l}\text { Sub-theme: Hope for } \\
\text { improvement }\end{array}$ & $\begin{array}{c}\text { It helps us to reflect more and to find the strength to be able to go ahead in our lives and think we can win this fight in } \\
\text { the future (E1). } \\
\begin{array}{c}\text { (...) it gives me more hope, it's very good, I think about improving, getting my transplant, and then I think everything } \\
\text { will be all right (E27). }\end{array}\end{array}$ \\
\hline $\begin{array}{l}\text { Sub-theme: Coping with } \\
\text { hemodialysis }\end{array}$ & $\begin{array}{l}\text { (...) it helps us to face the treatment with more willpower (E2). } \\
\text { (...) when you get prayed for, God reaches our hearts and we become stronger (E21). }\end{array}$ \\
\hline
\end{tabular}

\section{DISCUSSION}

Hemodialysis can be a hard experience to endure and intensely perceived and manifested, and it results in hemodynamic changes arising from the extracorporeal circulation process for a person who suffers from chronic kidney disease. Therefore it requires rigorous monitoring and evaluation of the vital signs, before, during and after the treatment from the nursing professional ${ }^{(24)}$.

A difficult adaptation process is established from this perspective and it is necessary for the individual to mobilize resources to deal with renal problems and all the changes that come from the treatment ${ }^{(25)}$. In this context, prayer is a resource capable of promoting religious/spiritual coping, bringing hope, and helping those who use it to feel stronger and safer to deal with the disease, the treatment and the whole context they are in. In addition, it can be considered a complementary practice to treatment ${ }^{(10-11)}$.

The inter-group analysis displayed a significant statistical reduction only in heart rate $(\mathrm{p}=0.027)$ and respiratory rate $(\mathrm{P}<0.001)$ after the prayer in the intervention group in this 
study. However, in the intra-group analysis, the comparison between pre- and post-intervention evaluations showed that the patients who were prayed for achieved a statistically significant reduction $(\mathrm{P}<0.001)$ in all evaluated vital signs, while those who were not prayed for displayed an increase, especially in systolic blood pressure and respiratory rate, which presented a significant statistical increase $(p<0.001)$. This result corroborates with the study ${ }^{(11)}$ aimed at assessing the effectiveness of prayer in reducing anxiety in cancer patients who are undergoing chemotherapy. This study also displayed a significant reduction in respiratory rate and blood pressure on patients that were prayed for. Another study $^{(26)}$ conducted an integrative review of the literature and found that patients engaged in religious practices display a reduction in heart rate, respiratory rate, and blood pressure. Therefore, it is possible to conclude that prayer is a complementary practice to conventional treatment, since it assists in the reduction of analyzed vital signs and may lead to the reduction of catecholamines, which cause elevation of pressure ratings ${ }^{(26)}$.

Thus, prayer can be considered a relevant practice to stabilize vital signs in cases of diseases and in healthy people as well, as it was observed that praying the Hail Mary prayer improved cardiac function patterns and reduced the respiratory rate in 23 healthy adults in a study ${ }^{(27)}$.

The findings from the experimental phase of this study are corroborated through the volunteers' testimonies. The participants characterize hemodialysis as an obstacle in their lives and it places them in a context of suffering generated by a complex treatment when facing the disease. The analysis of the expressions, meaningful phrases, tears and tone of voice of the interviewees showed that the vision they have on the hemodialysis treatment transcends the physical realm, as they characterize it as a "place" that brings about feelings of solitude, isolation and melancholy.

Spirituality is a resource associated with hope and capable of providing support in coping with diseases causing changes and suffering in the human being, and it should be encouraged by professionals in the care of the patient undergoing hemodialysis ${ }^{(28)}$. During the interviews, many stated the intervention provided moments of reflection on their lives, future and possibilities of restoring their healthy condition.
Hemodialysis changes life dynamics and demands adaptation to new routines and behaviors, which may require sacrifices and abdications and can bring about difficulties, exhaustion, and stress ${ }^{(7)}$. Perhaps that is why many individuals describe spirituality as a force to drive their lives and promotes hope for overcoming the difficult situations arising from CKD and hemodialysis.

Therefore, the inclusion of spiritual practices in health care can broaden the available resources to provide comfort, offering the patient benefits from the interaction between body and spirit. Thus, prayer can be considered a possibility of spiritual care, capable of exerting positive effects on the treatment of people with $\mathrm{CKD}^{(8-11)}$.

Finally, it is possible to conclude that the results from this study are relevant to clinical practice, since they present scientific evidence on prayer and display a possibility of application that can be used by the nurse in the care of the patient undergoing hemodialysis, taking into account the patient's needs and spirituality.

Possibly, the high level of religiosity in the sample was a limitation in this study. In addition, some singularities of the IG, such as higher educational level, better family income, and shorter treatment time may also be considered as biases. Therefore, new investigations should be conducted in people with different religious/spiritual aspects.

\section{CONCLUSION}

The results of the three evaluations pre- and post-intervention demonstrate that prayer had a satisfactory effect on patients undergoing hemodialysis. Prayer was effective in reducing the blood pressure, heart, and respiratory rates in the groups of patients studied.

Furthermore, it was possible to understand that people who suffer from $\mathrm{CKD}$ undergoing hemodialysis perceive prayer as a complementary intervention with a positive aspect, capable of providing relief from the suffering of the illness process.

The nursing team can use prayer as a method to offer spiritual support to the patients, satisfy their spiritual needs and provide support to the patient in dealing with the disease, treatment, anxiety, and lifestyle changes brought about from hemodialysis.

\section{RESUMO}

Objetivo: Avaliar o efeito da prece sobre a pressão arterial, a frequência cardíaca e respiratória em paciente com insuficiência renal crônica e conhecer sua percepção a respeito da intervenção. Método: Ensaio clínico controlado, randomizado, duplo cego com uma amostra de voluntários, randomizados em grupo intervenção $(n=42)$ e grupo controle $(n=37)$. Foram aplicados, por meio de entrevista, um questionário de características sociodemográficas, clínicas e espirituais e o Índice de Religiosidade da Universidade de Duke, além da mensuração da pressão arterial, frequência cardíaca e respiratória. A prece foi ministrada em três momentos diferentes, durantes semanas alternadas. Os dados qualitativos foram organizados e analisados por meio da Análise Temática. Resultados: A amostra totalizou 95 voluntários randomizados. $\mathrm{Na}$ análise intragrupos foi observada uma redução estatisticamente significativa $(\mathrm{P}<0001)$ dos valores de pressão arterial, frequência cardíaca e respiratória em todas as análises das pessoas que receberam a prece. A análise qualitativa resultou nos temas A Prece em um "Lugar de Sofrimento" e Avaliação Positiva e nos subtemas Alívio do Sofrimento, Esperança de Superação, Enfrentamento do Tratamento Hemodialítico. Conclusão: A prece reduziu os valores da pressão arterial, frequência cardíaca e respiratória de pacientes com insuficiência renal crônica e a avaliação dos voluntários em relação à intervenção foi positiva. Registro Brasileiro de Ensaios Clínicos: RBR-2zv39y.

Pressão Arterial; Insuficiência Renal; Espiritualidade; Cura pela Fé; Enfermagem Holística. 


\section{RESUMEN}

Objetivo: Evaluar el efecto de la plegaria sobre la presión arterial, la frecuencia cardiaca y respiratoria en paciente con insuficiencia renal crónica y conocer su percepción respecto de la intervención. Método: Ensayo clínico controlado, randomizado, doble ciego con una muestra de voluntarios aleatorizados en grupo de intervención $(n=42)$ y grupo control $(n=37)$. Fueron aplicados, por medio de encuesta, un cuestionario de rasgos sociodemográficos, clínicos y espirituales y el Indice de Religiosidad de la Universidad de Duke, además de la medición de la presión arterial, frecuencia cardiaca y respiratoria. La plegaria fue impartida en tres momentos distintos, durante semanas alternadas. Los datos cualitativos fueron organizados y analizados mediante el Análisis Temático. Resultados: La muestra totalizó 95 voluntarios randomizados. En el análisis intragrupos se observó una reducción estadísticamente significativa $(\mathrm{P}<0001)$ de los valores de presión arterial, frecuencia cardiaca y respiratoria en todos los análisis de las personas que recibieron la plegaria. El análisis cualitativo resultó los temas La Plegaria en un "Lugar de Sufrimiento" y Evaluación Positiva y los subtemas Alivio del Sufrimiento, Esperanza de Superación, Enfrentamiento del Tratamiento Hemodialítico. Conclusión: La plegaria redujo los valores de la presión arterial, frecuencia cardiaca y respiratoria de paciente con insuficiencia renal crónica, y la evaluación de los voluntarios con relación a la intervención fue positiva. Registro Brasileño de Ensayos Clínicos: RBR-2zv39y.

\section{DESCRIPTORES}

Presión Arterial; Insuficiencia Renal; Espiritualidad; Enfermería; Curación por la Fé; Enfermería Holistica.

\section{REFERENCES}

1. Meuwesen WP, du Plessis JM, Burger JR, Lubbe MS, Cockeran M. Prescribing patterns of non-steroidal anti-inflammatory drugs in chronic kidney disease patients in the South African private sector. Int J Clin Pharm. 2016;38(4):863-9.

2. Moreira DS, Vieira MR. Crianças em tratamento dialítico: a assistência pelo enfermeiro. Arq Ciênc Saúde. 2010;17(1):27-34.

3. Bortolotto LA. Hipertensão arterial e insuficiência renal crônica. Rev Bras Hipertens. 2008;15(3):152-5.

4. Karkar A. Modalities of hemodialysis: quality improvement. Saudi J Kidney Dis Transpl. 2012;23(6):1145-61.

5. Gabriel D, Martin L, Ramos D, Batistao S, Tomaz I, Calixto R, et al. Role of hypervolemia in hypertension of patients with chronic renal failure in hemodialysis. J Hypertens. 2004;22:S159.

6. Lin CC, Han CY, Pan IJ. A qualitative approach of psychosocial adaptation process in patients undergoing long-term hemodialysis. Asian Nurs Res. 2016;9(1):39-41.

7. Ramirez SP, Macêdo DS, Sales PM, Figueiredo SM, Daher EF, Araújo SM, etal. The relationship between religious coping, psychological distress and quality of life in hemodialysis patients. J Psychosom Res. 2012;72(2):129-35.

8. Chaves ECL, Carvalho TP, Carvalho CC, Grasselli CSM, Lima RS, Terra FS, et al. Associação entre bem-estar espiritual e autoestima em pessoas com insuficiência renal crônica em hemodiálise. Psicol Reflex Crít. 2015;28(4):737-43.

9. Cabral JP. A prece revisitada: comemorando a obra inacabada de Marcel Mauss. Relig Soc.2009;29(2):13-28.

10. Esperandio MRG, Ladd KL. I heard the voice. I felt the presence": prayer, health and implications for clinical practice. Religions. 2015;6:670-85. DOI: 10.3390/rel6020670

11. Carvalho CC, Chaves ECL, lunes DH, Simão TP, Grasselli CSM, Braga CG. The effectiveness of prayer in reducing anxiety in cancer patients. Rev Esc Enferm USP. 2014;48(4):684-90. DOI: http://dx.doi.org/10.1590/S0080-623420140000400016

12. Lepherd L. Spirituality: everyone has it, but what is it? Int J Nurs Pract. 2015;21(5):566-74.

13. Simão TP, Caldeira S, Carvalho EC. The effect of prayer on patients' health: systematic literature review. Religions. $2016 ; 7(1): 11$.

14. McCloskey JC, Bulechek GM. Classificação das intervenções de enfermagem. Porto Alegre: Artmed; 2013.

15. Brasil. Ministério da Saúde; Secretaria de Atenção à Saúde, Departamento de Atenção Básica. Estratégias para o cuidado da pessoa com doença crônica: hipertensão arterial sistêmica [Internet]. Brasília; 2013 [citado 2015 abr. 17]. Disponível em: http://bvsms.saude.gov.br/ bvs/publicacoes/estrategias_cuidado_pessoa_doenca_cronica.pdf

16. Schulz KF, Altman DG, Moher D; CONSORT Group. CONSORT 2010 statement: updated guidelines for reporting parallel group randomised trials. Obstet Gynecol. 2010;115(5):1063-70.

17. Lucchetti G, Granero Lucchetti AL, Peres MF, Leão FC, Moreira-Almeida A, Koenig HG. Validation of the Duke Religion Index: DUREL (Portuguese Version). J Relig Health. 2012;51(2):579-86.

18. Koenig H, Patterson G, Meador K. Religion Index for psychiatric research: a 5-item measure for use in health outcomes studies. Am J Psychiatry. 1997;154(1)885-6.

19. Belghazi J, Feghali RNEL, Moussalem T, Rejdych M, Asmar RG. Validation of four automatic devices for self-measurement of blood pressure according to the International Protocol of the European Society of Hypertension. Vasc Health Risk Manag. 2007;3(4):389-400.

20. British Hypertension Society. Clinical Research Updates [Internet]. 2012 [cited 2016 Mar 07]. Available from: www.bhsoc.org/research/

21. Wilkinson JM, Leuven KV. Fundamentos de enfermagem: teoria, conceitos e aplicações. São Paulo: Roca; 2010.

22. Coutinho ESF, Cunha GM. Basic concepts in epidemiology and statistics for reading controlled clinical trials. Rev Bras Psiquiatr. $2005 ; 27(2): 146-51$.

23. Braum V, Clarke V. Using thematic analysis in Psychology. Qual Res Psychol. 2006;3(2):77-101.

24. Santana SS, Fontenelle T, Magalhães LM. Assistência de enfermagem prestada aos pacientes em tratamento hemodialítico nas unidades de nefrologia. Rev Cient ITPAC [Internet]. 2013 [citado 2016 jun. 13];6(3). Disponível em: http://www.itpac.br/arquivos/Revista/63/5.pdf

25. Gerogianni S, Babatsikou F, Gerogianni G, Grapsa E, Vasilopoulos G, Zyga S, et al. 'Concerns of patients on dialysis: a research study'. Health Sci J. 2014;8(4):423-37. 
26. Lindberg DA. Integrative review of research related to meditation, spirituality, and the elderly. Geriatr Nurs. 2005;26(6):372-7.

27. Bernardi L, Sleight P, Bandinelli G, Cencetti S, Fattorini L, Wdowczyc-Szulc J, et al. Effect of rosary prayer and yoga mantras on autonomic cardiovascular rhythms: comparative study. BMJ. 2001;323(7327):1446-9.

28. Ottaviani AC, Souza EN, Drago NC, Mendiondo MSZ, Pavarini SCl, Orlandi FS. Hope and spirituality among patients with chronic kidney disease undergoing hemodialysis: a correlational study. Rev Latino Am Enfermagem. 2014;22(2):248-54.

Financial support:

Conselho Nacional de Desenvolvimento Científico e Tecnológico (CNPq), and Ministério da Educação, Programa de Educação Tutorial (MEC/PET). 